UDC 371.3::811.111

159.953.5.072-053.8

\author{
Małgorzata Jedynak ${ }^{*}$ \\ University of Wrocław \\ English Studies Department \\ Wrocław, Poland
}

\title{
LEARNING STRATEGIES TRAINING AND AUTONOMY DEVELOPMENT IN A GROUP OF ADULT LEARNERS
}

\begin{abstract}
The article aims at emphasizing the importance of language learning strategies in development of adult learners' autonomy. In the theoretical part, it presents the background of language learning strategies, defines the concept of a language learning strategy, and provides the taxonomy of language learning strategies proposed by various researchers. The paper also presents the concept of learner autonomy and points to the link between language learning strategies and learner autonomy. The empirical part of the paper is a presentation of the research in which late-starters of English in their mid and late fifties were exposed to language learning strategy training in order to develop their language learning autonomy.
\end{abstract}

Key words: Learning strategies, learner autonomy, FL teaching to adults

\section{Introduction}

For the last two decades there has been a great interest in foreign language learning strategies and their effectiveness. The considerable body of research devoted to this issue refers to adolescent foreign language learners (e.g. Michońska-Stadnik, 1996). Since the strategy training requires

E-mail address: gosiajedynak@poczta.onet.pl 
some linguistic awareness, it is most effective in formal operation stage individuals. Thus, child learners, due to their cognitive restraints, are not subjected to this training. As to adult L2 learners, it is frequently taken for granted that they are already autonomous individuals with the extensive knowledge of learning strategies; hence introducing strategy training in their case is pointless.

Contrary to these popular beliefs, adult learners, especially in the Polish education setting, need even more learning strategies training than their younger counterparts. The former, being educated in the time of communism when the grammar-translation and audio-lingual methods were dominant, had hardly any chances to experience autonomous learning or learning strategies training. The foreign languages taught at that time were mainly Latin and Russian. Socioeconomic and political changes made it possible for English to spread out in the Eastern Europe, while the role of Russian was diminished. Since the 1990s there has been a great demand for teaching English among adults. There have also been many methodological changes in L2 classrooms in the last twenty years, inspired by communicative approach and constructivism. Many adult learners never had a chance to experience innovations in teaching foreign languages. Consequently, they may have problems with taking responsibility for their own learning, expecting from FL teachers to guide and evaluate it. To facilitate learning process of this specific group of learners and develop their autonomy, L2 teachers need to implement learning strategies training.

There are many reasons for promoting the development of learner autonomy in a FL classroom. Since it is impossible to transmit all knowledge in a given subject in a classroom, the learners need to be independent to find other ways of language learning. During communication in a real life situation, the teacher will not assist the learner, so the learner should manage on his/her own. Learning is more effective in the situation when the learner is actively and emotionally involved in this process. It is believed that the command of learning strategies enables the learner to be more autonomous. A crucial question, however, is whether this interdependence holds true for adult learners of a foreign language.

The primary objective of the paper is to show whether using the specific language learning strategies influences the development of learner autonomy in a group of learners in their mid and late fifties. The article has a twofold structure. The theoretical part outlines the background of learning strategies and autonomy. In the empirical part the author reports 
Małgorzata Jedynak Learning strategies training and autonomy development in ...

on her research findings which show that there is some influence of the use of the three learning strategies on the process of developing FL learner autonomy among adults learning English in a private language school.

\section{Theoretical considerations}

\subsection{Learning strategies - origin, definitions, taxonomies}

It was in 1960s when the researchers got interested in language learning strategies. Their research was mostly influenced by the work of cognitive psychologists who claimed that learners are active during their learning process using different methods (Williams \& Burden 2004: 149). Since the 1970s SLA research has been thriving. Consequently, teachers have become more aware of the significance of individual differences in learning process. The SLA research has provided the information on the attributes of good language learners with regard to learning strategies, styles and personal traits. Brown (2000: 123-124) notices that, in spite of the fact that the list of good learner's features was hypothetical, the investigation encouraged other researchers to carry out a number of researches in the field of learning strategies, such as Wenden and Rubin, O' Malley and Chamot, Ellis, and Oxford (Williams \& Burden 2004: 149).

There have been many attempts to define learning strategies. As Michońska-Stadnik (1996: 22) notices, the term strategy was used first by Selinker in his popular article about interlanguage. Selinker (1972, in Michońska-Stadnik 1996: 22-23) asserts that interlanguage results among others from foreign language learning strategies as well as communication strategies. Furthermore, Selinker describes strategies as cognitive processes similarly to O'Malley and Chamot (ibid.). David Nunan (1999:171), in turn, perceives language learning strategies as "the mental and communicative procedures learners use in order to learn and use language". Oxford (1989, in Ellis 2008: 703- 704) explicates the term of learning strategies as "behaviours or actions which learners use to make language learning more successful, self-directed and enjoyable". An interesting view is presented by Tarone (1980, in Ellis 2008: 704) for whom strategy is "an attempt to develop linguistic and sociolinguistic competence in the target language". Tarone also enhances the fact that language learning strategies are used by the learners for acquiring new 
linguistic and sociolinguistic knowledge about the target language, as opposed to skills learning strategies which are employed for becoming more proficient in listening, speaking, reading and writing in the target language. Despite the variety of definitions of language learning strategies, it is worth noticing that all the researchers perceive them as useful for organizing the learning process and as contributing to success in language learning. Undoubtedly, the most detailed description of learning strategies was provided by Rebecca Oxford. The twelve characteristics which she listed in her book constitute a complete and comprehensive description of language learning strategies. She notices that they refer to actions taken by the learner, contribute to communicative competence, allow learners to become more self- directed, and expand the role of teachers. Furthermore, they are conscious, flexible, problem oriented, and not always observable. Oxford also claims that they are influenced by a variety of factors, involve many aspects of the learner, not just these related to cognition. Language learning strategies support learning both directly and indirectly and they can be taught (Oxford, 1990: 9).

It is a widespread belief that the use of learning strategies correlates with success in learning. This view is also confirmed by Oxford (2001, in Ellis 2008: 713), who mentions two reasons for which learning strategies are significant. First of all they are "tools for active, self-directed involvement, which is essential for developing communicative competence" (Oxford 1990: 1). Secondly, "learners who have developed appropriate learning strategies have greater self-confidence and learn more effectively" (Nunan 1999: 172).

It was noticed by Oxford (1994: 1-2) that learners use various kinds of strategies with a different frequency. There are some determinants which influence the choice of learning strategy such as motivation, gender, cultural background, attitudes and beliefs, type of task, learning style, age and L2 proficiency level.

As to taxonomy of learning strategies, there is no one recognized system of learning strategies classification. This constitutes some difficulty in the SLA research. The researchers propose different typologies which can be organized into the following groups:

1) related to successful language learners (Rubin 1975, in Oxford 1994: 2), 
Małgorzata Jedynak Learning strategies training and autonomy development in ...

2) based on psychological functions (O'Malley and Chamot 1990, in Oxford 1994:2)

3) dealing with guessing, language monitoring, formal and functional practice (Bialystok 1981, in Oxford 1994: 2)

4) dealing with communication strategies (Tarone 1983, in Oxford 1994: 2)

5) related to separate language skills (Cohen 1990, in Oxford 1994: 2)

6) based on different styles or types of learners (Sutter 1989, in Oxford 1994: 2)

Undoubtedly, the classifications put forward by Rubin, O'Malley, and Oxford, are the most applicable in SLA research field. Rubin is the pioneer in the learning strategy research. She divides strategies into those which directly deal with language learning and those which have indirect influence on the language learning process. Furthermore, Rubin distinguishes three main groups of language strategies: learning strategies, communication strategies and social strategies (Rubin 1981, 1987, in Williams\& Burden 2004: 149-151). O'Malley (1985, in Hismanoglu 2000: 4), in turn, divides language learning strategies into: metacognitive strategies, cognitive strategies and socioaffective strategies. The classification made by Rebecca Oxford seems to be the most frequently used by SLA researchers. Direct strategies proposed by her are further divided into three subcategories: memory strategies, cognitive strategies and compensation strategies. Indirect strategies, in turn, include metacognitive strategies, affective strategies and social strategies (Oxford 1990: 37-135).

\subsection{The main issues related to autonomy development in L2 learning}

The term language learning autonomy was introduced by Holec (1981, in Benson 2001: 8). He finds some interdependence between the sociopolitical situation and learner autonomy emergence. He claims that at the end of the 1960s in Western Europe the social development was no longer associated with growing material prosperity but was connected to the advance in standard of life. This transformation was related to the growing respect for an individual person within the community. This view corresponds to the one represented by Benson (2001: 7), who notices that the political context in Europe in the late 1960s and the beliefs that 
appeared then had a great impact on autonomy development in the education context. Benson also makes a point that learner autonomy is related to formal learning.

The idea of learner autonomy in the field of language teaching arises from the Council of Europe's Modern Languages Project launched in 1971. Within this project, the Centre de Recherches et d'Applications en Langues (CRAPEL) at the University of Nancy in France was founded. The originator of CRAPEL was Yves Chalon, who is considered the father of language learner autonomy. CRAPEL focused first on the research in language learner autonomy among adult learners. The centre contributed to selfdirected learning by (among others) self-access centres and the concept of learner training. After Chalon's death in 1972, Henri Holec became a leader of CRAPEL (Benson 2001: 7-8).

There is some disagreement among the researchers as to the definition of learner autonomy. It is mainly due to the problem with identifying a clear cut boundary between learner responsibility and learner autonomy. For Scharle and Szabo (2007: 3), one of the main features of a responsible learner is his/her awareness of the importance of the efforts he/she makes while learning. Such a learner is more intrinsically than extrinsically motivated and he/she finds cooperation as an effective way of learning. Furthermore, he/she is aware of his/her learning which he/she constantly monitors and searches occasions for learning novelties. It seems that the characterization of a responsible learner generates the definition of an autonomous learner.

As far as the term of learner autonomy is concerned, the researchers propose various definitions. According to Holec (1981: 3), learner autonomy is "the ability to take charge of one's learning". Holec develops his definition explaining that this ability refers to setting the objectives, defining the contents and progressions, selecting methods and techniques to be used, monitoring the procedure of acquisition, and finally evaluating what has been acquired (ibid). Little (1991: 4), unlike Holec, emphasizes in his definition the significance of psychological element in learner autonomy, and not its cognitive aspect. He asserts that learner autonomy is "a capacity - for detachment, critical reflection, decision-making, and independent action. It presupposes, but also entails, that the learner will develop a particular kind of psychological relation to the process and content of his learning".

An autonomous learner, as Omaggio (1978, in Wenden 1991: 4142) notices, may be characterized with certain characteristics. He/she is 
aware of his/her learning styles and strategies. He/she is also active during learning process and is enthusiastic about taking some risks during learning. Moreover, he/she is ready to guess something that he/she does not know. An autonomous learner pays attention both to fluency and accuracy, makes and tests hypothesis about the target language. According to Omaggio he/she is also tolerant towards the culture of the target language. Little (1990, in Benson 2001: 48), in turn, made an attempt to clarify what the learner autonomy is not. For the researcher it is not "a synonym for selfinstruction", and it "does not entail an abdication of responsibility on the part of the teacher". Furthermore, it is not "another teaching method" or "a steady state achieved by learners" (ibid.).

The occurrence of learner autonomy is not a particular moment but systematic and continuous process (Scharle and Szabo 2007: 9). There are three stages in learner autonomy development which were distinguished by the two researchers. As Scharle and Szabo notice, in the process of learner autonomy emergence, one stage evolves into the other in a smooth way. In the first stage, called "raising awareness", new perspectives and ways of thinking are demonstrated to the learners. The subsequent stage, called "changing attitudes" is a gradual process involving practice of the abilities acquired at the foregoing phase. In the last phase, "transferring roles", the responsibility is placed on the learner rather than the teacher, which leads to major modification in classroom management. This shift is the most challenging and difficult stage for teachers.

A question relevant for a topic in this paper is why learner autonomy should be fostered. The answer to the question is partly provided by Nunan (1988: 3), who argues that it is impossible to transmit all knowledge in a given subject in a classroom. During real life communication the teacher will not assist the learner so the learner should manage on his or her own (Cotterall 1995: 220). It is generally acknowledged that a learner will achieve better results in language learning if he is more actively and emotionally involved in learning process. When the teacher and the learner decide together on taking responsibility for learning and about the content and goals of the learning, the latter will be more motivated towards learning (Scharle and Szabo 2007: 4).

As to approaches to learner autonomy development, there is no universal way of doing it. Benson (2001: 109) notices that any way of motivating learners to take charge of their learning can be regarded as an instrument for fostering learner autonomy. Yet, as Benson continues there 
are some practices which may enhance learner autonomy development. Among them there are resource-based, technology-based, learner-based, classroom-based, curriculum-based and teacher-based approaches (Benson 2001: 111).

In resource-based approach, FL teachers allow learners to select materials, evaluate the learning process and take control over learning plans. Technology-based approach is similar to resource-based approach; however the emphasis is put on technologies used in self-directed learning. Learner-based approach, in turn, aims at developing behavioural and psychological changes that will lead learners to take control over their education and become more responsible for both the process and the product of learning. In other areas of autonomy practice described by Benson as classroom-based, curriculum-based, and teacher-based approaches, the role of the classroom, the curriculum, and the teacher is emphasized. The underlying assumption of these approaches is that learners will be able to make autonomous decisions concerning their learning if they are provided with cooperative and supportive environment. This may be achieved by providing learners with efficient learning strategies, assisting them to identify their own preferred ways of learning, developing skills needed to negotiate the curriculum, or encouraging learners to set their own objectives.

\section{Empirical Part}

\subsection{Research aims, questions, hypotheses}

The main aim of the experimental study was to check whether adult learners of English who used the three language learning strategies are more autonomous in their learning process than their counterparts who were not exposed to strategy training. Hence, the main research question posed by the researcher was whether language learning strategies have any impact on learner autonomy. Since there are numerous groups and subgroups of learner strategies proposed by various researchers, the author decided to focus only on three of them: 1) strategies of compensating for missing knowledge, 2) strategies of organizing and evaluating learning, and 3 ) learning with others. Therefore, the specific research questions concern 
the relationship between the three types of selected learning strategies and learner autonomy.

It might seem obvious that there is a positive correlation between language learning strategies use and development of learner autonomy. Nevertheless, for the reasons outlined in the introduction to the article, the author decided to conduct research among adults who are neglected in this type of research. Additionally, the author finds it challenging to examine a group of Polish adult learners, who, being in their mid and late fifties, have never been trained in learning strategies use or any other techniques of autonomy development.

The author hypothesizes that the null hypothesis may be supported, which means that no relationship between learner strategies and autonomy development will be found. However, the researcher also considers positive or negative interdependence between these two variables.

\subsection{Research description: variables, subjects, procedure}

The researcher identified a number of variables in her study. The independent variable refers to learning strategy training, which means both presentation of the three language learning strategies to the adult learners by the teacher and their practice. The dependent variable, in turn, represents learner autonomy, which may be operationalised as the ability of taking the responsibility for learning process. The level of the adult students' autonomy is measured by a structured autonomy questionnaire. Undoubtedly, there might be the impact of various intervening variables on the relationship between the independent and the dependent variables such as the teacher effectiveness in strategy training, the adult learners' motivation and their prior experience with English. The researcher made an attempt to control one variable, namely the adult learners' prior exposure to learning strategies. Two subjects with the prior strategy training were eliminated from the study.

As it has been mentioned above the subjects were all adult learners of English ranging in age from 55 to 59 years. The research was conducted in the private language school CANYDEY in Wrocław. The learners' motives for learning the English language varied. The majority of them studied it in order to be able to communicate with their family members (grandchildren, sons-in-law and daughters-in-law). The others needed 
the language to use it abroad while travelling or doing business. The total number of students participating in the study was 40; however, two of them were eliminated since they had prior learning strategies experience.

The first part of the study was to screen subjects in terms of their knowledge and use of the language learning strategies. 38 subjects filled in the questionnaire on language learning strategies (SILL) by Rebecca Oxford, which was translated into the native language of the subjects, that is Polish (see Appendix 1). In the original questionnaire there were 50 questions and six parts in the questionnaire representing various strategy groups: 1) remembering more effectively, 2) using mental processes, 3) compensating for missing knowledge, 4) organizing and evaluating learning, 5) managing emotions, and 6) learning with others. However, the researcher reduced the number of questions to focus only on these which were related to the three investigated strategies. In the strategy questionnaire the subjects had a choice between the five answers for each question. Below there is a list with the options provided to the subjects and the number of points assigned to each statement.

$\begin{array}{ll}\text { 'never or almost never true' } & -1 \text { point } \\ \text { 'rather not true' } & -2 \text { points } \\ \text { 'sometimes it is true' } & -3 \text { points } \\ \text { 'mostly it is true' } & -4 \text { points } \\ \text { 'always or almost always' } & -5 \text { points }\end{array}$

Since the highest score the subject could obtain in each part of the learning strategy questionnaire was 30, the researcher made an assumption that only these subjects can be skipped out from the study who scored at least $50 \%$ in each part.

There were 6 subjects who declared using the strategies on a regular basis either always or most of the time. Thus, they were excluded from further research. The other 32 subjects were divided into two groups: the control group (15 subjects) and the experimental one (17 subjects).

In the second part of the research, the experimentals were introduced to the strategy training, while the control group was not provided with any treatment. In the strategy training the English teacher used a number of various tasks. In the first set of tasks the subjects focused on these strategies which help compensate for missing knowledge. The tasks involved fill-in- 
the gap exercises, language games in which the learners worked in teams to prepare definitions of words, or the games in which the learners were working on synonyms to various English words. In the second set of tasks the strategies of organizing and evaluating the learning process were introduced.

The adult learners filled in the chart on the language learning progress they noticed. They also shared their experiences on how they learn and what way they find most effective for them. Finally, in the third set, the adult learners were taught the ability of learning with others and with various learning materials. The subjects had a chance to practice their skills with a native speaker of English who was invited to the classroom. They were also requested to prepare the list of learning materials they use and share it with the peers.

After a three month period both groups of subjects were requested to fill in the questionnaire on the development of their autonomy as the learners of English (see Appendix 2). The questionnaire was based on Stadnik's learner autonomy questionnaire and consisted of twelve questions. The subjects could choose between two options, namely 'I agree' or 'I do not agree' for which either 1 point or 0 point were assigned correspondingly. It was assumed that the score from 7 to 12 points was indicative of learner autonomy.

\subsection{The results of the study and their discussion}

The data from the autonomy questionnaire is first presented for each group. Then the data is presented in a collective manner.

\begin{tabular}{|c|c|c|c|c|c|c|c|c|c|c|c|c|c|c|c|c|c|c|c|}
\hline 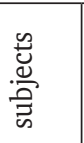 & 1 & 2 & 3 & 4 & 5 & 6 & 7 & 8 & 9 & 10 & 11 & 12 & 13 & 14 & 15 & 16 & 17 & $\begin{array}{l}\text { ฐే } \\
\text { ్ }\end{array}$ & 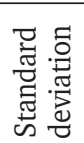 \\
\hline 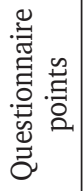 & 8 & 8 & 12 & 10 & 9 & 9 & 9 & 10 & 8 & 9 & 8 & 3 & 3 & 3 & 5 & 3 & 4 & 7.1 & 2.86 \\
\hline
\end{tabular}

Table 1. The results obtained from the experimental group with strategy training 
As shown in Table 1, the majority of subjects (11 subjects) obtained 7 points and more while 6 respondents scored below 7 points. Therefore, the former can be said to display some low level of autonomy. The mean for the group amounts to 7.1 which indicates that despite strategy training the learners are autonomous; however the level of autonomy may be described as low. The group of respondents was rather homogenous $(\mathrm{SD}=2.83)$.

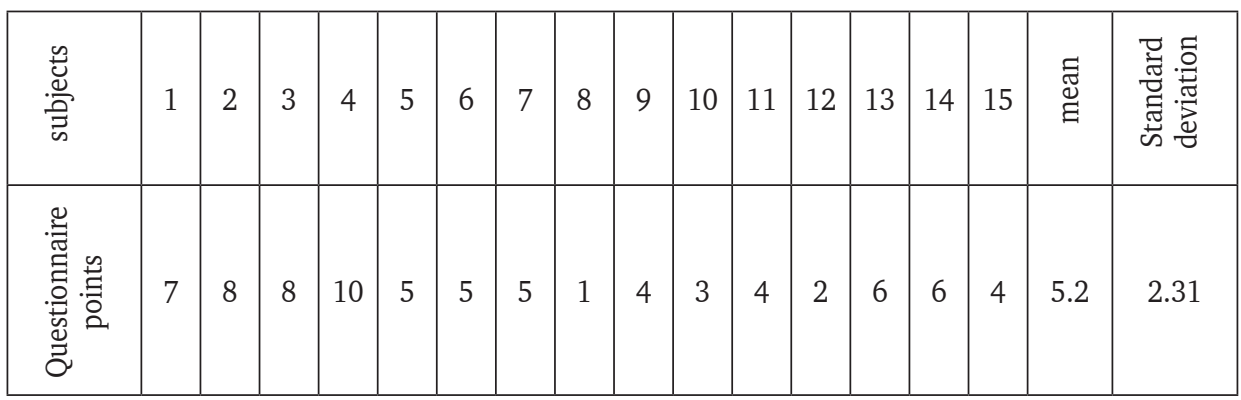

Table 2. The results obtained from the control group without strategy training

As shown in Table 2, in the control group there are four subjects whose final score may be indicative of learner autonomy. The majority of participants (11 subjects) scored below 7 points, which may imply that these learners are not autonomous. The mean for the group was 5.2, which may be interpreted as an indication of the lack of autonomy. The control group was homogenous $(\mathrm{SD}=2.31)$.

Since the main aim of the study was to check whether learning strategy training has an impact on autonomy, the results obtained by the two groups on the autonomy questionnaire were compared. Firstly, Pearson's chi-squared goodness-of-fit test was conducted to check whether or not an observed frequency distribution differs from a theoretical distribution. The analysis did not show statistically significant differences between the groups: $\operatorname{chi}^{2}(1)=0.12$ and $p=0.724$. This implies that the control and the experimental groups were equipotent.

Then, Kolmogorov-Smirnov test (K-S test) for the equality of continuous, one-dimensional probability distributions was applied to compare the two samples (two-sample K-S test). The statistical analysis showed that in the experimental group the distribution was not similar 
to the normal distribution: K-S $=0.26 ; \mathrm{p}=0.003$. This implies the application of non-parametric statistical test to compare the two groups. The analysis was conducted by means of U Mann-Whitney test to check whether the experimental group differed from the control one in terms of the points obtained on the test. The analysis did not show statistically significant difference: $\mathrm{Z}=1.77 ; \mathrm{p}=0.077$. This means that the subjects in the experimental group were not different from the control group subjects in terms of the autonomy questionnaire points. Since there are no differences in the autonomy level between the groups, the null hypothesis put forward in the section 3.1 is supported while the alternative hypotheses are refuted.

\section{Final thoughts}

In the study it was proved that strategy training procedure had no impact on learner autonomy development. However, one should be careful with making any generalisations such as that the adult L2 learners are not capable of developing autonomous behaviour while learning English. There are undoubtedly many limitations of the study which should make the reader treat the obtained results with caution. One should bear in mind that the strategy training concerned only three strategy groups. It might have happened that the same students provided with the training including other strategies would have achieved better results on the autonomy questionnaire. Furthermore, the learners in the study may not be psychologically ready to be autonomous and take responsibility for their learning. Autonomy development is a gradual process and the duration of the strategy training could be too short for some of the adult learners in the study. One may also question the research sample and its size. In the bigger sample there would be a chance to eliminate the impact of an intervening variable such as a personality factor related to motivation. There were two students in the study who resisted the strategy training claiming that they were too old to be told how to learn effectively. These students did not participate actively in the assigned tasks, which also might have had some negative effect on the rest of the group.

As to the very research procedure, there seems to be a problem with the objective measurement of the learners' autonomy level. It seems justified to introduce the autonomy questionnaire before and after the 
strategy training. Only having pre-treatment and post-treatment results can one really judge the level of learners' autonomy.

\section{References}

Benson, Phil (2001). Teaching and Researching Autonomy in Language Learning Edinburgh: Pearson Education Limited.

Brown, H. Douglas (1994). Teaching by Principles. An Interactive Approach to Language Pedagogy New Jersey: Prentice Hall Regents.

Brown, H. Douglas (2000). Principles of Language Learning and Teaching New York: Longman Pearson Education Company.

Chamot, Anna Uhl (2004). Issues in Language Learning Strategy Research and Teaching. Electronic Journal of Foreign Language Teaching Available on: http://e-flt.nus.edu.sg/v1n12004/chamot.htm (DE: 02.09.2010).

Cohen, A. D. (1998). Strategies in Learning and Using a Second Language. London: Longman.

Coles, Martin J., Robinson, William D. (1991). Teaching Thinking, a Survey of Programmes in Education. London: Bristol Classical Press.

Cotterall, Sara (1995). Developing a Course Strategy for Learner Autonomy. ELT Journal 49/ 3. Oxford University Press Available on: http://eltj. oxfordjournals.org/content/49/3/219.full.pdf (DE: 16.11.2010).

Crabbe, David (1993). Fostering Autonomy from within the Classroom: the Teacher's Responsibility. System Available on: http://www. sciencedirect.com/science?_(DE: 20.11.2010).

Dam, L. (1990). Learner Autonomy in Practice. In Gathercole, I. (ed.). 1990 CILT. Great Britain: Bourne Press.

Dudeney, Gavin, Hockly Nicky (2007). How to...Teach English with Technology. Edinburgh: Longman Pearson Education Limited.

Ellis, Rod (2003). Second Language Acquisition Oxford: Oxford University Press.

Ellis, Rod (2008). The Study of Second Language Acquisition Oxford: Oxford University Press.

Gardner, D., Miller L. (1999). Establishing Self- Access: From Theory to Practice. Cambridge: Cambridge University Press.

Hismanoglu, Murat (2000). Language Learning Strategies in Foreign Language Learning and Teaching. The Internet TESL Journal Available on: http:// iteslj.org/Articles/Hismanoglu-Strategies.html (DE: 02.09.2010). 
Holec, Henry (1981). Autonomy in Foreign Language Learning. Oxford: Oxford University Press.

Knowles, Malcolm (1976). The Modern Practice of Adult Education. New York: Association Press.

Lessard-Clouston, Micheal (1997). Language Learning Strategies: An Overview for L2 Teachers. The Internet TESL Journal Available on: http://iteslj.org/Articles/Lessard-Clouston-Strategy.html (DE: 02.09.2010).

Little, David (1991). Learner Autonomy. 1: Definitions, Issues and Problems. Dublin: Authentic.

Michońska-Stadnik, Anna (1996). Strategie Uczenia się i Autonomia Ucznia $w$ Warunkach Szkolnych [Learning Strategies and Learner's Autonomy in School Conditions]. Wrocław: Wydawnictwo Uniwersetu Wrocławskiego.

Nisbet, John, Shucksmith, Janet (1991). Learning Strategies. New York: Routledge.

Nunan, David (1988). Syllabus Design. Oxford: Oxford University Press.

Nunan, David (1999). Second Language Teaching \& Learning Boston: An International Thomson Publishing Company.

O'Malley, J. Michael, Chamot, Anna Uhl (1995). Learning Strategies in Second Language Acquisition Cambridge: Cambridge University Press.

Oxford, Rebecca L., Nyikos, M. (1989). Variables affecting choice of language learning strategies by university students. The modern Language Journal.

Oxford, Rebecca L. (1990). Language Learning Strategies: What Every Teacher Should Know. Boston: Heinle\& Heinle.

Oxford, Rebecca L. (1994). Language Learning Strategies: An Update University of Alabama Online Resources: Digests Available on: http:// www.cal.org/resources/digest/oxford01.html (DE: 16.11.2010).

Scharle, Agota, Szabo, Anita (2007). Learner Autonomy. A guide to developing learner responsibility. Cambridge University Press.

Stern, Hans Heinrich (1992). Issues and Options in Language Teaching. Oxford: Oxford University Press.

Wenden, Anita (1991). Learner Strategies for Learner Autonomy. London: Prentice Hall International.

Williams, Marion, Burden, Robert L. (2004). Psychology for Language Teachers: a Social Constructivist Approach. Cambridge: Cambridge University Press. 


\section{Appendix 1}

The questionnaire on the three selected learning strategies (based on SILL by R. Oxford).

Assign the points to all the statements which are below.

$\begin{array}{ll}\text { 'never or almost never true' } & -1 \text { point } \\ \text { 'rather not true' } & -2 \text { points } \\ \text { 'sometimes it is true' } & -3 \text { points } \\ \text { 'mostly it is true' } & -4 \text { points } \\ \text { 'always or almost always' } & -5 \text { points }\end{array}$

\section{Part I}

1. Staram się odgadnąć znaczenie słowa, którego nie znam.

2. Kiedy podczas rozmowy nie mogę sobie przypomnieć słowa, używam zamiast niego gestów.

3. Kiedy nie znam słowa, wymyślam je sam/a.

4. Nie czuję potrzeby, żeby sprawdzać w słowniku każde nowe słowo, które pojawia się w tekście.

5. Podczas rozmowy staram się przewidzieć, co druga osoba zaraz powie.

6. Kiedy nie mogę przypomnieć sobie słowa lub zwrotu używam innych o takim samym znaczeniu.

\section{Part II}

1. Szukam okazji, żeby móc używać języka angielskiego.

2. Zauważam swoje błędy i staram się uczyć i wyciągać z nich wnioski.

3. Zwracam uwagę na osoby, które mówią po angielsku.

4. Staram się dowiedzieć, $\mathrm{w}$ jaki sposób mogę lepiej uczyć się języka angielskiego.

5. Obserwuję swoje postępy w nauce języka angielskiego.

6. Wyznaczam sobie kolejne cele w nauce języka angielskiego.

\section{Part III}

1. Interesuję się kultura krajów anglojęzycznych. 
2. Zadaję pytania w języku angielskim.

3. Proszę o pomoc w nauce osoby, dla których język angielski jest językiem ojczystym.

4. Cwiczę język angielski z innymi osobami.

5. Proszę rodzimych użytkowników języka angielskiego, żeby poprawiali moje błędy w trakcie mojej wypowiedzi.

6. Wyznaczam sobie kolejne cele w nauce języka angielskiego.

\section{Appendix 2}

The questionnaire in Polish on adult learners' autonomy.

Circle only one option that refers to you.

1. Staram się uzyskać informacje jak mogę bardziej efektywnie uczyć się języka angielskiego.

zgadzam się nie zgadzam się

2. Przed każdym kursem wyznaczam sobie cele, do których chcę dążyć w nauce języka angielskiego.

$$
\text { zgadzam się nie zgadzam się }
$$

3. Uważam, że to ja a nie nauczyciel ponoszę odpowiedzialność za sukces w nauce języka angielskiego.

zgadzam się nie zgadzam się

4. Korzystam z literatury i czasopism w języku angielskim.

zgadzam się nie zgadzam się

5. Korzystam z różnego rodzaju słowników.

zgadzam się nie zgadzam się

6. Monitoruję i oceniam swoje postępy w nauce języka angielskiego.

zgadzam się nie zgadzam się

7. Jestem przygotowany/a do zajęć z języka angielskiego i odrabiam zadania domowe.

zgadzam się nie zgadzam się

8. Jestem systematyczny/a w nauce języka angielskiego i odrabianiu zadań domowych.

zgadzam się nie zgadzam się 
9. Planuję swój dzień w ten sposób, żeby mieć czas na naukę języka angielskiego.

zgadzam się nie zgadzam się

10. Poszukuję okazji, żeby móc porozmawiać $\mathrm{z}$ osobami w języku angielskim (przez Internet, podczas wyjazdów służbowych, wakacji itp.)

$$
\text { zgadzam się nie zgadzam się }
$$

11. Korzystam $\mathrm{z}$ Internetu w celu znalezienia materiałów do nauki języka angielskiego oraz ciekawostek na temat anglojęzycznych krajów.

$$
\text { zgadzam się nie zgadzam się }
$$

12. Oglądam filmy oraz programy telewizyjne w języku angielskim.

$$
\text { zgadzam się nie zgadzam się }
$$

Received: 1 September, 2013

Accepted for publication: 25 October, 2013

Малгосјата Јединак

\section{ОБУКА ВЕЗАНА ЗА СТРАТЕГИЈЕ УЧЕЊА И РАЗВИЈАҢЕ АУТОНОМИЈЕ УЧЕЊА НА ПРИМЕРУ ЈЕДНЕ ГРУПЕ ОДРАСЛИХ}

\section{Сажетак}

Овај рад има циљ да истакне важност стратегија учења језика у развоју аутономије учења код одраслих. У теоријском делу износи се позадински оквир стратегија учења језика, одређује се појам стратегије учења језика, и наводи се таксономија стратегија учења језика на основу предлога различитих истраживача. Поред тога, представља се појам аутономије ученика у учењу и указује се на везу између стратегија учења језика и ученичке аутономије. У емпиријском делу рада представљено је истраживање у којем су одрасли почетници у учењу енглеског језика (у узрасту касних педесетих година) били изложени обуци везаној за стратегије учења језика како би развили сопствену аутономију у учењу језика.

Кључне речи: стратегије учења, аутономија ученика, настава страног језика одраслима 